\title{
PARTISIPASI PEDAGANG DALAM PENGELOLAAN SAMPAH
}

\author{
Yuriani Lampus \\ Welson M. Wangke \\ Martha M. Sendow
}

\begin{abstract}
This study aims to determine the participation of market traders in waste management in Pasar Pinasungkulan Manado City. This research was conducted at Pasar Pinasungkulan Manado City located in Karombasan Urban Village at Manado City. This research was conducted for 3 months from January 2017 until March 2017. Sources of data taken in this research are primary and secondary data. Primary data was obtained through interviews with traders. Secondary data is obtained from PD Pasar Paal Dua office. The sampling method used in this research is the accidental sampling method, which is self-determined of 92 respondents. The data analisis was descriptive based on table of frequency. Based on the results of descriptive analysis it can be seen that the index of market participant participation is high enough with the score obtained is 1.827.
\end{abstract}

Keywords: participation, traders, waste management, Pinasungkulan Market, Manado City

\begin{abstract}
ABSTRAK
Penelitian ini bertujuan untuk mengetahui partisipasi pedagang dalam pengelolaan sampah pasar. Penelitian ini dilakukan di Pasar Pinasungkulan Kota Manado yang terletak di Kelurahan Karombasan, Kecamatan Sario, Kota Manado. Penelitian ini dilaksanakan selama 3 bulan dari bulan Januari sampai bulan Maret 2017. Sumber data yang diambil dalam penelitian ini adalah data primer dan data sekunder. Data primer diperoleh melalui wawancara dengan pedagang pasar di Pasar Pinasungkulan Kota Manado. Wawancara dilakukan dengan menggunakan daftar pertanyaan yang telah dipersiapkan terlebih dahulu. Data sekunder dipeloleh dari kantor PD Pasar Paal Dua. Metode pengambilan sampel menggunakan metode sampling aksidental, yaitu ditentukan sendiri sebanyak 92 responden. Analisis yang di gunakan dalam penelitian ini adalah metode analisis secara deskriptif dan disajikan dalam bentuk tabel frekuensi. Berdasarkan hasil analisis deskriptif maka dapat diketahui bahwa angka indeks partisipasi pedagang pasar tergolong cukup baik dengan skor yang didapat yaitu 1.827.
\end{abstract}

Kata Kunci: partisipasi, pedagang, pengelolaan sampah, Pasar Pinasungkulan, Kota Manado 


\section{PENDAHULUAN}

\section{Latar Belakang}

Keberadaan sampah akan berdampak langsung terhadap lingkungan hidup. Dikhawatirkan sampah yang akan semakin menumpuk dapat merusak ekosistem lingkungan, terutama ekosistem di lingkungan sekitar tempat pembuangan akhir (TPA). Sampah tidak hanya merusak ekosistem lingkungan tetapi juga menyebabkan polusi. Polusi yang ditimbulkan oleh sampah antara lain polusi air, polusi bau dan polusi tanah (Kuncoro, 2009). Di lingkungan Pasar Pinasungkulan di Kota Manado, banyak sampah yang timbul dari aktivitas pedagang pasar, dari sisa-sisa hasil penjualan pedagang pasar, khususnya pedagang pasar dari hasil pertanian, yang membuat suasana lingkungan sekitar pasar menjadi tidak bersih. Partisipasi pedagang dalam pengelolaan sampah adalah keterlibatan pedagang dalam ikut serta bertanggung jawab baik aktif maupun pasif untuk mewujudkan kebersihan lingkungan.Peningkatan jumlah sampah yang tidak diikuti oleh perbaikan dan peningkatan sarana dan prasarana pengelolaan sampah mengakibatkan permasalahan sampah menjadi kompleks, antara lain sampah tidak terangkut dan terjadi pembuangan sampah dengan sembarangan, sehingga dapat pembuangan sampah, kurangnya kesadaran dan kemauan masyarakat dalam mengelola dan membuang sampah, masih kurangnya pemahaman masyarakat tentang manfaat sampah, serta keengganan masyarakat memanfaatkan kembali sampah, karena sampah dianggap sesuatu yang kotor dan harus dibuang. Berbagai hal tersebut menyebabkan menurunnya kualitas lingkungan yang berdampak negatif bagi masyarakat.

Pasar merupakan salah satu lembaga yang paling penting dalam institusi ekonomi. Pasar muncul sebagai pusat tukar-menukar, perdagangan sebagai kegiatan tukar menukar yang sebenarnya, dan uang sebagai alat penukar, pasar juga sebuah tempat bertemunya penjual dan pembeli yang melayani transaksi jual-beli. Jumlah sampah yang dihasilkan oleh sampah pasar semakin banyak seiring dengan meningkatnya aktivitas perdagangan dan meningkatnya jumlah pedagang dan pembeli serta keanekaragaman barang yang diperjualbelikan. Sampah dapat menimbulkan bahan cemaran yang akan menyebabkan pencemaran lingkungan dan dapat berpengaruh langsung terhadap kesehatan manusia. Penanganan sistem pengelolaan persampahan suatu kota harus dilaksanakan dengan efisien dan efektif, sehingga dapat dicapai hasil maksimal sesuai yang diharapkan oleh masyarakat dan pemerintah. Pengelolaan sampah pasar bukan saja tanggung jawab pemerintah semata, tapi sangat ditentukan oleh tingkat partisipasi para pedagang pasar.Oleh karena itu, diperlukan upaya nyata dalam menyelesaikan permasalahan sampah yang salah satunya dengan meningkatkan partisipasi pedagang dalam pengelolaan sampah pasar terlebih rasa tanggungjawab terhadap lingkungannya.

Untuk menjaga lingkungan diperlukan partisipasi aktif dan sukarela dari seluruh pedagang pasar untuk mau mengurangi volume sampah yang ada di tempat pembuangan sampah sementara (TPS). Jika pedagang pasar telah mengetahui manfaat dan dampaknya dalam mengelola sampah pasar maka pemerintah dan pedagang harus memikirkan bagaimana cara mengolah sampah yang efektif dan efisien sehingga dapat mengurangi polusi yang ditimbulkan dari sampah tersebut dan lingkunganpun menjadi bersih dan sehat. Dasar hukum pengelolaan sampah mengacu pada UU No 18 Tahun 2008, tentang Pengelolaan Sampah. Dalam undang-undang tersebut dinyatakan yang dimaksud dengan sampah ialah sisa kegiatan sehari-hari manusia dan/atau proses alam yang berbentuk padat. Adapun definisi pengelolaan sampah adalah kegiatan yang sistematis, menyeluruh, dan berkesinambungan yang meliputi pengurangan dan penanganan sampah. Kegiatan penanganan sampah sebagai berikut :

a. Pemilahan dalam bentuk pengelompokkan dan pemidahan sampah sesuai dengan jenis, jumlah dan/sifat sampah.

b. Pengumpulan dalam bentuk pengambilan dan pemindahan sampah dari sumber sampah ke tempat penampungan sementara atau tempat pengolahan sampah terpadu.

c. Pengangkutan dalam bentuk membawa sampah dari sumber dan/atau dari tempat penampungan sampah sementara atau dari 
tempat pengolahan sampah terpadu menuju ke tempat pemrosesan terakhir.

d. Pengolahan dalam bentuk mengubah karakteristik, komposisi dan jumlah sampah, dan/atau.

e. Pemrosesan akhir sampah dalam bentuk pengembalian sampah dan/atau residu hasil pengolahan sebelumnya ke media lingkungan secara aman.

\section{Perumusan Masalah}

Berdasarkan latar belakang yang telah dikemukakan, maka yang menjadi masalah dalam penelitian ini yaitu, bagaimana partisipasi pedagang pasar dalam pengelolaan sampah pasar di Pasar Pinasungkulan Kota Manado?

\section{Tujuan Penelitian}

Penelitian ini bertujuan untuk mengetahui partisipasi pedagang pasar dalam pengelolaan sampah pasar di Pasar Pinasungkulan, Kota Manado.

\section{Manfaat Penelitian}

Dengan adanya penelitian ini diharapkan adanya kebijakan dari Pemerintah kepada pedagang untuk meningkatkan partisipasi.

\section{METODE PENELITIAN}

\section{Waktu dan Tempat Penelitian}

Penelitian ini dilaksanakan selama tiga bulan dari bulan Januari 2017 sampai bulan Maret 2017 mulai dari persiapan, pengambilan data sampai penyusunan laporan dan ujian akhir. Tempat penelitian di Pasar Pinasungkulan Kota Manado.

\section{Metode Pengumpulan Data}

Data yang dikumpulkan dalam penelitian ini yaitu data primer dan data sekunder. Data primer diperoleh melalui wawancara dengan pedagang Pasar Pinasungkulan di Kota Manado. Wawancara dilakukan dengan menggunakan daftar pertanyaan yang telah disiapkan terlebih dahulu. Data sekunder diperlukan melalui Kantor PD Pasar.

\section{Metode Pengambilan Sampel}

Populasi pedagang di Pasar Pinasungkulan Kota Manado berjumlah1.028 orang. Banyaknya sampel dari populasi $(\mathrm{n}=$ 92), dihitung dengan rumus slovin. Dan sampel di tarik dengan menggunakan metode sampling aksidental.

\section{Konsep Pengukuran Variabel}

Variabel-variabel yang dikaji dalam penelitian ini adalah :

1. Karakteristik responden, meliputi :

Umur Responden terakhir dinyatakan dalam tahun, tingkat pendidikan, dan penghasilan.

2. Pengukuran bentuk-bentuk partisipasi pedagang pasar dalam pengelolaan sampah pasar.

Dinyatakan selalu dengan skor tiga, jika responden melakukan kesepuluh partisipasi di atas lebih dari tiga kali dalam seminggu, selanjutnya dinyatakan kadang-kadang dengan skor dua, jika responden melakukan kesepuluh partisipasi di atas hanya di bawah tiga kali dalam seminggu, dan jika responden tidak melakukan kesepuluh partisipasi di atas dinyatakan tidak pernah dengan skor satu.

a. Partisipasi mengumpulkan sampah dagangan ke TPS.

1. Partisipasi mengumpulkan sampah selalu dengan skor 3

2. Partisipasi mengumpulkan sampah kadangkadang dengan skor 2

3. Partisipasi mengumpulkan sampah tidak pernah dengan skor 1

b. Partisipasi menegur orang yang membuang sampah sembarangan.

1. Partisipasi menegur orang yang membuang sampah sembarangan selalu dengan skor 3

2. Partisipasi menegur orang yang membuang sampah sembarangankadang-kadang dengan skor 2

3. Partisipasi menegur orang yang membuang sampah sembarangan tidak pernah dengan skor 1

c. Partisipasi memberikan gagasan untuk kegiatan kebersihan.

1. Partisipasi memberikan gagasan untuk kegiatan kebersihan selalu dengan skor 3

2. Partisipasi memberikan gagasan untuk kegiatan kebersihan kadang-kadang dengan skor 2 
3. Partisipasi memberikan gagasan untuk kegiatan kebersihan tidak pernah dengan skor 1

d. Partisipasi menghadiri rapat/pertemuan untuk membicaran masalah kebersihan.

1. Partisipasi menghadiri rapat/pertemuan untuk membicaran masalah kebersihan selalu dengan skor 3

2. Partisipasi menghadiri rapat/pertemuan untuk membicaran masalah kebersihan kadang-kadang dengan skor 2

3. Partisipasi menghadiri rapat/pertemuan untuk membicaran masalah kebersihan tidak pernah dengan skor 1

e. Partisipasi membayar retribusi sampah.

1. Partisipasi membayar retribusi sampah selalu dengan skor 3

2. Partisipasi membayar retribusi sampah kadang-kadang dengan skor 2

3. Partisipasi membayar retribusi sampah tidak berjalan baik dengan skor 1

f. Partisipasi membuang sampah pada tempatnya.

1. Partisipasi membuang sampah pada tempatnya selalu dengan skor 3

2. Partisipasi membuang sampah pada tempatnya kadang-kadang dengan skor 2

3. Partisipasi membuang sampah pada tempatnya tidak pernah dengan skor 1

g. Partisipasi menjaga kondisi kebersihan sampah di tempat berusaha.

1. Partisipasi menjaga kondisi kebersihan sampah di tempat berusahaselalu dengan skor 3

2. Partisipasi menjaga kondisi kebersihan sampah di tempat berusahakadang-kadang dengan skor 2

3. Partisipasi menjaga kondisi kebersihan sampah di tempat berusaha tidak pernah dengan skor 1

h. Partisipasi menyediakan tempat sampah sementara sendiri.

1. Partisipasi menyediakan tempat sampah sementara sendiri selalu dengan skor 3

2. Partisipasi menyediakan tempat sampah sementara sendiri kadang-kadang dengan skor 2

3. Partisipasi menyediakan tempat sampah sementara sendiri tidak pernah dengan skor 1

i. Partisipasi kerjasama antar pedagang dalam menjaga kebersihan.
1. Partisipasi kerjasama antar pedagang dalam menjaga kebersihan selalu dengan skor 3

2. Partisipasi kerjasama antar pedagang dalam menjaga kebersihan kadang kadang dengan skor 2

3. Partisipasi kerjasama antar pedagang dalam menjaga kebersihan tidak pernah dengan skor 1

j. Partisipasi melakukan evaluasi bersama terhadap kebersihan di lingkungan sekitar pasar.

1. Partisipasi melakukan evaluasi bersama terhadap kebersihan di lingkungan sekitar pasar selalu dengan skor 3

2. Partisipasi melakukan evaluasi bersama terhadap kebersihan di lingkungan sekitar pasar kadang-kadang dengan skor 2

3. Partisipasi melakukan evaluasi bersama terhadap kebersihan di lingkungan sekitar pasar tidak pernah dengan skor 1

Perhitungan Menggunakan Rumus dibawah ini:

Skor x Jumlah Indikator x Jumlah Responden

Penentuan Penilaian baik buruknya partisipasi pedagang dalam pengelolaan sampah berdasarkan total skor dari keseluruhan responden dari masing-masing indikator partisipasi pedagang, sebagai berikut :

Jumlah skor $1841-2760=$ Partisipasi sangat tinggi

Jumlah skor $921-1840=$ Partisipasi tinggi

Jumlah skor $0-920=$ Partisipasi rendah

Skor yang masuk diantara $1841-2760$, maka dapat disimpulkan bahwa partisipasi pedagang dalam pengelolaan sampah tergolong sangat Baik, selanjutnya skor yang masuk diantara 921 - 1840, maka dapat disimpulkan bahwa partisipasi pedagang dala pengelolaan sampah tergolong cukup baik, skor yang masuk diantara 0 - 920, maka dapat disimpulkan bahwa partisipasi pedagang dalam pengelolaan sampah tergolong kurang baik.

\section{Analisis Data}

Data yang diperoleh dari penelitian ini akan dianalisis secara deskriptif dan disajikan dalam bentuk table frekuensi. Tabel frekuensi adalah salah satu bentuk penyajian data yang dibuat agar data yang telah dikumpulkan dalam jumlah yang sangat banyak dapat disajikan dalam bentuk yang jelas dan 
baik. Dengan kata lain, tabel frekuensi dibuat untuk menyederhanakan bentuk dan jumlah data sehingga ketika disajikan kepada para pembaca dapat dengan mudah dipahami atau dinilai.

\section{HASIL DAN PEMBAHASAN}

\section{Gambaran Umum Daerah Penelitian}

\section{Letak Geografis}

Pasar Pinasungkulan adalah salah satu pusat perbelanjaan yang ada di Kota Manado, yang terletak di bagian ujung selatan Kecamatan Sario. Kedudukan pasar berada di Kelurahan Karombasan yang berhadapan dengan kompleks pertokoan Pinasungkulan Plaza. Adapun batas-batas dari pasar Pinasungkulan adalah sebagai berikut : Sebelah utara berbatasan dengan kelurahan Pakowa, sebelah selatan berbatasan dengan Kelurahan Karombasan, sebelah barat berbatasan dengan Kelurahan Ranotana Weru. Jalan masuk yang menghubungkan Pasar Pinasungkulan adalah jalur aspal yang dapat dilalui oleh beberapa kendaraan jenis angkutan kota dari beberapa wilayah kota Manado, bahkan di sekitar lokasi pasar terdapat terminal kendaraan jenis angkutan luar kota. Dengan kondisi ini, menjadikan Pasar Pinasungkulan merupakan salah satu pasar yang ramai di Kota Manado karena banyak dikunjungi pembeli baik yang ada di sekitar lokasi pasar maupun yang jauh dari lokasi pasar dan merupakan tempat pertemuan pedagang-pedagang dari berbagai daerah Minahasa bahkan juga di luar daerah Minahasa seperti Kotamobagu dan Gorontalo. Kegiatan di Pasar Pinasungkulan berlangsung setiap hari dimulai pada jam 04.00 pagi sampai jam 21.00. Paling ramai konsumen datang berbelanja di pasar ini sekitar jam 07.00 sampai jam 11.00 dan mulai sepi pada jam 12.00 sampai jam 15.00. Kegiatan jual beli mulai ramai lagi sekitar jam 16.00 sampai jam 20.00. Kegiatan jual beli di Pasar Pinasungkulan ratarata berhenti pada jam 21.00.Sesuai data dari Dinas Pasar Pinasungkulan Karombasan, luas pasar yaitu $2 \mathrm{Ha}$, dengan banyaknya kios permanen 170 buah, bak-bak penjualan bantuan Inpres 63 buah, tenda-tenda/pelataran sebanyak
700 buah dan jumlah pedagang yang berjualan 1.028 pedagang.

\section{Profil Pasar}

Pasar Pinasungkulan Karombasan merupakan salah satu pasar besar yang berada di Kota Manado berdasarkan Peraturan Daerah no. 14 tahun 2000 tanggal 3 Januari 2000 Dinas Pasar dialihkan status menjadi Perusahan Daerah Kota Manado sehingga saat ini dikelola secara langsung oleh PD Pasar kota Manado. Di Pasar Pinasungkulan karombasan ini terdapat penjual-penjual mulai dari pedagang kaki lima hingga toko-toko besar yang dibangun didalamnya. Pasar Pinasungkulan Karombasan ini telah menjadi pusat perbelanjaan bagi masyarakat sekitar yang sering dibanjiri pedagang maupun pengunjung.

\section{Karakteristik Responden}

\section{Jenis Kelamin Pedagang}

Dalam penelitian ini jenis kelamin sangat berpengaruh dalam berpartisipasi untuk pengelolaan sampah, sebagian besar laki-laki adalah yang sangat berperan dalam hal berpartisiasi tenaga untuk kebersihan lingkungan pasar, karena laki-laki tidak mengenal lelah atau tidak sungkan-sungkan dalam mengangkat sampah.

Tabel 1. Jenis Kelamin Responden

\begin{tabular}{cccc}
\hline No & Jenis Kelamin & $\begin{array}{c}\text { Jumlah } \\
\text { Responden } \\
\text { (orang) }\end{array}$ & Presentase \\
\hline 1 & Laki-Laki & 51 & 55,43 \\
2 & Perempuan & 41 & 44,56 \\
\hline & Jumlah & 92 & 100,00 \\
\hline
\end{tabular}

Sumber: Data Primer (2017)

Tabel 1 Menunjukkan bahwa, jumlah responden perempuan 51 responden $(55,43 \%)$ dan responden laki-laki berjumlah $41(44,56)$.

\section{Umur Pedagang}

Umur seseorang sangat berpengaruh terhadap kemampuan seseorang untuk bekerja secara fisk maupun cara berpikirnya, semakin tinggi umur pedagang semakin berkurang kemampuan dalam bekerja juga cara berpkirnya, sedangkan pedagang yang berumur 
muda pada umumnya mempunyai kemampuan fisik yang lebih baik dan cara berpikir yang masih detail. Menurut hasil penelitian umur pedagang responden dapat $d$ lihat pada Tabel 2.

Tabel 2. Umur Responden

\begin{tabular}{cccc}
\hline No & Umur & $\begin{array}{c}\text { Jumlah Responden } \\
\text { (orang) }\end{array}$ & Presentase(\%) \\
\hline 1 & $20-29$ & 4 & 4,34 \\
2 & $30-39$ & 27 & 29,34 \\
3 & $40-49$ & 42 & 45,65 \\
4 & $50-59$ & 15 & 16,3 \\
5 & $60-69$ & 3 & 3,26 \\
\hline \multicolumn{4}{c}{ Jumlah } \\
\multicolumn{2}{l}{ Sumber: Data Primer (2017) }
\end{tabular}

Tabel 2 menunjukkan jumlah responden pada umur anggota pedagang. Umur 20-29 tahun menunjukan presentase yaitu sebanyank4 responden $(4,34 \%)$ selanjutnya berada pada usia 40-49 tahun menunjukan presentase sebanyak 42responden $(45,65 \%)$, pada usia 50 59 tahun menunjukan presentase sebanyak 15 responden (16,30\%), dan pada usia 60-69 tahun menunjukan presentase sebanyak 3 responden (3,26\%), pada usia 70-79 tahun menunjukan presentase sebanyak 1 responden $(1,08 \%)$.

\section{Tingkat Pendidikan Responden}

Peranan pendidikan formal sangat penting dalam usaha meningkatakan kualitas seseorang karena berguna dalam pembangunan pribadi serta peningkatan intektual dan wawasan seseorang.Berdasarkan hasil penelitian, tingkat pendidikan responden bervariasi mulai dari tingkat Sekoah Dasar (SD), SLTP/SMP, SMA, dan S1. Komposisi tingkat pendidikan responden dalam penelitian ini dapat di liahat pada Tabel 3.

Tabel 3. Pendidikan Responden

\begin{tabular}{cccc}
\hline No & Pendidikan & $\begin{array}{c}\text { Jumlah Responden } \\
\text { (orang) }\end{array}$ & $\begin{array}{c}\text { Presentase } \\
(\%)\end{array}$ \\
\hline 1 & SD & 36 & 33,12 \\
2 & SLTP/SMP & 38 & 34,96 \\
3 & SMA/SMK & 16 & 14,72 \\
4 & S1 & 2 & 1,84 \\
\hline & Jumlah & 92 & 100,00 \\
\hline
\end{tabular}

Sumber: Data Primer (2017)

Tabel 3 menunjukkan responden menurut tingkat pendidikan anggota pedagang pasar. Tingkat pendidikan SD berjumlah 36 responden atau $(33,12 \%), \quad$ SLTP/SMP berjumlah 38 atau $(34,96)$, SMA/SMK berjumlah 16 responden atau $(14,72)$, dan $\mathrm{S} 1$ berjumlah 2 responden atau $(1,84)$.

\section{Penghasilan Responden}

Penghasilandalam suatu pekerjaan berpengaruh pada seseorang untuk melakukan hal-hal positif dalam suatu pekerjaan seperti halnya berpartisipasi, semakin tinggi penghasilan yang di dapat oleh orang tersebut maka semakin tinggi rasa pedulinya terhadap pekerjaan yang dikerjakan.

Tabel 4. Penghasilan Pedagang

\begin{tabular}{|c|c|c|c|}
\hline No & $\begin{array}{l}\text { Penghasilan } \\
\text { (Rp) }\end{array}$ & $\begin{array}{l}\text { Jumlah Responden } \\
\text { (orang) }\end{array}$ & $\begin{array}{c}\text { Presentase } \\
(\%)\end{array}$ \\
\hline 1 & $\begin{array}{l}2.000 .000- \\
4.000 .000\end{array}$ & 32 & 18,48 \\
\hline 2 & $\begin{array}{c}5.000 .000- \\
7.000 .000\end{array}$ & 10 & 19,57 \\
\hline 3 & $\begin{array}{l}8.000 .000- \\
9.000 .000\end{array}$ & 6 & 6,52 \\
\hline 4 & $\begin{array}{c}10.000 .000- \\
15.000 .000\end{array}$ & 18 & 18,47 \\
\hline 5 & $\begin{array}{l}16.000 .000- \\
20.000 .000\end{array}$ & 5 & 14,13 \\
\hline 6 & $\begin{array}{l}21.000 .000- \\
30.000 .000\end{array}$ & 8 & 8,67 \\
\hline 7 & $\begin{array}{c}45.000 .000- \\
75.000 .000\end{array}$ & 13 & 14,13 \\
\hline & Jumlah & 92 & 100,00 \\
\hline
\end{tabular}

Sumber: Data Primer (2017)

Tabel 4 menunjukkan penghasilan responden, penghasilan Rp.2.000.000,Rp.4.000.000 (18,48\%) 17 orang, Rp.5.000.000- Rp7.000.000(19,57\%) 18 orang, Rp.8.000.000-Rp.9.000.000 (6,25\%) 6 orang, $\begin{array}{lll}\text { Rp.10.000.000-Rp.15.000.000 (18,47\%) } 17 & 17\end{array}$ orang, Rp.16.000.000-Rp.20.000.000 (14,13\%) 13 orang, Rp.21.000.000-Rp.30.000.000 $(8,67 \%) \quad 8$ orang, dan Rp.45.000.000Rp.75.000.000 (14,13\%) 13 orang.

\section{Bentuk-bentuk Partisipasi Pedagang Dalam Pengelolaan Sampah Pasar.}

\section{Partisipasi Mengumpulkan Sampah Dagangan Ke TPS.}

Partisipasi mengumpulkan sampah dagangan artinya apakah pedagang membuang secara langsung sampah dagangan mereka ke TPS. Dalam hal ini pedagang berinisiatif untuk membawah sampahnya ke TPS tanpa 
menunngu petugas untuk datang mengangkat sampah tersebut dapat dilihat pada Tabel 5.

Tabel 5. Partisipasi Mengumpulkan Sampah Dagangan Ke

\begin{tabular}{|c|c|c|c|c|c|}
\hline No & $\begin{array}{c}\text { Tingkat } \\
\text { Partisipasi }\end{array}$ & $\begin{array}{c}\text { Alternatife } \\
\text { Skor }\end{array}$ & $\begin{array}{c}\text { Jumlah } \\
\text { Responden } \\
\text { (Orang) }\end{array}$ & $\begin{array}{c}\text { Persentase } \\
(\%)\end{array}$ & $\begin{array}{l}\text { Total } \\
\text { Skor }\end{array}$ \\
\hline 1 & Selalu & 3 & 19 & 20,65 & 57 \\
\hline 2 & $\begin{array}{l}\text { Kadang- } \\
\text { kadang }\end{array}$ & 2 & 10 & 10,86 & 20 \\
\hline 3 & $\begin{array}{c}\text { Tidak } \\
\text { Pernah }\end{array}$ & 1 & 63 & 68,47 & 63 \\
\hline & Jumlah & & 92 & 100,00 & 140 \\
\hline
\end{tabular}

Sumber: Data Primer (2017)

Hasil Penelitian ini menunjukan bahwa 19 responden $(20,65 \%)$ pedagang memilih selalu mengumpulkan sampah pada tempat pembuangan sampah sementara karena rasa kepedulian yang datang dari diri sendiri tanpa mengharapkan petugas keberhisan, 10 responden $(10,86 \%)$ pedagang memilih kadangkadang di karenakan kesibukan pedagang sendiri dalam berdagang, dan 63 responden $(68,47 \%)$ pedagang memilih tidak sama sekali karena kelelahan dan hanya mengharapkan petugas kebersihan untuk mengumpulkan sampah di TPS.

\section{Partisipasi Menegur Orang Yang Membuang Sampah Sembarangan.}

Partisipasi menegur orang yang membuang sampah sembarangan artinya apakah pedagang menegur ketika melihat orang membuang sampah sembarangan di sekitar tempat penjualan pedagang tersebut, disaat kesibukan ataupun tidak dapat dilihat pada Tabel 6.

Tabel 6. Partisipasi Menegur Orang Yang Membuang Sampah Sembarangan

\begin{tabular}{lccccc}
\hline No & $\begin{array}{c}\text { Tingkat } \\
\text { Partisipasi }\end{array}$ & $\begin{array}{c}\text { Alternatife } \\
\text { Skor }\end{array}$ & $\begin{array}{c}\text { Jumlah } \\
\text { Responden } \\
\text { (Orang) }\end{array}$ & $\begin{array}{c}\text { Persentase } \\
(\%)\end{array}$ & $\begin{array}{c}\text { Total } \\
\text { Skor }\end{array}$ \\
\hline 1 & Selalu & 3 & 28 & 30,43 & 84 \\
2 & $\begin{array}{c}\text { Kadang- } \\
\text { kadang } \\
\text { Tidak }\end{array}$ & 2 & 36 & 33,12 & 72 \\
\hline & 1 & 28 & 30,43 & 84 \\
\hline & Jumlah & 92 & 100,00 & 184 \\
\hline
\end{tabular}

Hasil penelitian ini menunjukan bahwa, 28 responden $(30,43 \%)$ memilih selalu menegur orang yang membuang sampah sembarangan karena rasa peduli terhadap kebersihan lingkungan tempat penjualan, 31 responden $(33,12 \%)$ memilih kadang-kadang karena mereka hanya menegur jika orang tersebut membuang di area tempat berjualnya tersebut, tapi jika mereka melihat orang tersebut membuang sampah di tempat penjualan orang lain mereka hanya membiarkan begitu saja, dan 33 responden $(30,43 \%)$ memilih tidak sama sekali karena kesibukan melayani pembeli.

\section{Partisipasi memberikan gagasan untuk kegiatan kebersihan.}

Partisipasi memberikan gagasan untuk kegiatan kebersihan artinya apakah pedagang memberikan gagasan seperti ide-ide atau masukan untuk kegiatan keberhisan di lokasi penjualan dapat dilihat pada Tabel 7.

\begin{tabular}{cccccc} 
Tabel & $\begin{array}{c}\text { 7. Partisipasi } \\
\text { kebersihan }\end{array}$ & memberikan & gagasan & untuk kegiatan \\
\hline No & $\begin{array}{c}\text { Tingkat } \\
\text { Partisipasi }\end{array}$ & $\begin{array}{c}\text { Alternatife } \\
\text { Skor }\end{array}$ & $\begin{array}{c}\text { Jumlah } \\
\text { Responden } \\
\text { (Orang) }\end{array}$ & $\begin{array}{c}\text { Persentase } \\
(\%)\end{array}$ & $\begin{array}{c}\text { Total } \\
\text { Skor }\end{array}$ \\
\hline 1 & Selalu & 3 & 3 & 3,26 & 9 \\
2 & $\begin{array}{c}\text { Kadang- } \\
\text { kadang }\end{array}$ & 2 & 23 & 25 & 46 \\
3 & Tidak & 1 & 66 & 71,73 & 66 \\
\hline \multicolumn{7}{c}{ Jumlah } & 92 & 100,00 & 121 \\
\hline
\end{tabular}

Sumber: Data Primer (2017)

Hasil penelitian ini menunjukan bahwa, 3 responden memilih $(3,26 \%)$ memilih selalu memberikan gagasan untuk kegiatan kebersihan karena merasa kurang nyaman dengan kebersihan lingkungan tempat berjualnya, 23 responden $(25 \%)$ memilih kadang-kadang di karenakan kurangnya rasa peduli terhadap kebersihan lingkungan, dan 66 responden $(71,73 \%)$ memilih tidak sama sekali karena tidak peduli denga kebersihan lingkungan tempat penjualan.

\section{Partisipasi Menghadiri rapat/pertemuan Untuk Membicaran Masalah Kebersihan.}

Partisipasi menghadiri rapat/pertemuan untuk membicarakan masalah kebersihan artinya apakah pedagang menghadiri rapat/pertemuan saat mendapat undangan untuk membicarakan masalah kebersihan. Dalam hal ini pedagang meluangkan waktu untuk mengikuti rapat/pertemuan dapat dilihat pada Tabel 8. 
Tabel 8. Partisipasi Menghadiri rapat/pertemuan Untuk Membicaran Masalah Kebersihan

\begin{tabular}{cccccc}
\hline No & $\begin{array}{c}\text { Tingkat } \\
\text { Partisipasi }\end{array}$ & $\begin{array}{c}\text { Alternatife } \\
\text { Skor }\end{array}$ & $\begin{array}{c}\text { Jumlah } \\
\text { Responden }\end{array}$ & $\begin{array}{c}\text { Peresentase } \\
(\%)\end{array}$ & $\begin{array}{c}\text { Total } \\
\text { Skor }\end{array}$ \\
\hline 1 & Selalu & 3 & 1 & 1,08 & 3 \\
2 & $\begin{array}{c}\text { Kadang- } \\
\text { kadang }\end{array}$ & 2 & 3 & 3,26 & 6 \\
3 & Tidak & 1 & 88 & 95,65 & 88 \\
\hline & Jumlah & & 92 & 100,00 & 97 \\
\hline
\end{tabular}

Sumber: Data Primer (2017)

Hasil penelitian ini menunjuklan bahwa 1 responden $(1,08 \%)$ memilih selalu menghadiri rapat/pertemuan untuk membicarakan masalah kebersihan karena merupakan kewajiban pedaganng, 3 responden $(3,26 \%)$ memilih kadang-kadang dikarenakan kurangnya informasi dari atasan untuk melaksanan rapat/pertemuan, dan 88 responden $(95,65 \%)$ memilih tidak sama sekali karena kemalasan dan ada juga yang tidak sama sekali menerima informasi dari atasan untuk melaksanan rapat/pertemuan.

\section{Partisipasi Membayar Retribusi Sampah}

Partisipasi membayar retribusi sampah artinya apakah pedagang membayar retrubusi sampah pasar sesuai dan tepat pada waktunya sesuai dengan aturan yang di tetapkan dapat dilihat pada Tabel 9.

Tabel 9. Partisipasi Membayar Retribusi Sampah

\begin{tabular}{lccccc}
\hline No & $\begin{array}{c}\text { Tingkat } \\
\text { Partisipasi }\end{array}$ & $\begin{array}{c}\text { Alternatife } \\
\text { Skor }\end{array}$ & $\begin{array}{c}\text { Jumlah } \\
\text { Responden }\end{array}$ & $\begin{array}{c}\text { Peresentase } \\
(\%)\end{array}$ & $\begin{array}{c}\text { Total } \\
\text { Skor }\end{array}$ \\
\hline 1 & Selalu & 3 & 88 & 95,65 & 264 \\
2 & $\begin{array}{c}\text { Kadang- } \\
\text { kadang } \\
\text { Tidak }\end{array}$ & 2 & 4 & 4,34 & 8 \\
3 & 1 & 0 & 0 & 0 \\
\hline & Jumlah & 92 & 100,00 & 272 \\
\hline
\end{tabular}

Hasil penelitian ini menunjukan bahwa, 88 responden $(95,65 \%)$ memilih selalu membayar rertribusi sampah karena merupakan kewajiban sebagai pedagang, 4 responden $(4,34 \%)$ memilih kadang-kadang di karenakan kelalaian dari penagih tersebut yang sering datang sering juga tidak, dan tidak ada responden yang memilih tidak sama sekali karena setiap kali penagih datang mereka selalu membayar retribusi sampah.

\section{Partisipasi Membuang Sampah Pada Tempatnya}

Partisipasi membuang sampah pada tempatnya artinya apakah pedagang membuang sampah pada tempat yang sudah disediakan dapat dilihat pada Tabel 10.

\begin{tabular}{cccccc}
\multicolumn{6}{c}{ Tabel 10. Partisipasi Membuang Sampah Pada Tempatnya } \\
\hline No & $\begin{array}{c}\text { Tingkat } \\
\text { Partisipasi }\end{array}$ & $\begin{array}{c}\text { Alternatife } \\
\text { Skor }\end{array}$ & $\begin{array}{c}\text { Jumlah } \\
\text { Responden }\end{array}$ & $\begin{array}{c}\text { Persentase } \\
(\%)\end{array}$ & $\begin{array}{c}\text { Total } \\
\text { Skor }\end{array}$ \\
\hline 1 & Selalu & 3 & 90 & 82,8 & 270 \\
2 & Kadang- & 2 & 2 & 1,84 & 4 \\
& kadang & & & & \\
3 & Tidak & 1 & 0 & 0 & 0 \\
\hline & Jumlah & & 92 & 100,00 & 274 \\
\hline
\end{tabular}

Sumber: Data Primer (2017)

Hasil penelitian ini menunjukan bahwa, 91 responden $(82,8 \%)$ memilih selalu membuang sampah pada tempatnya karena untuk menjaga kebersihan lingkungan, 1 responden $(1,84 \%)$ memilih kadang-kadang di karenakan kelalaian dari pedagang itu sendiri, dan tidak ada responden yang memilih tidak sama sekali karena selalu membuang sampah pada tempatnya.

\section{Partisipasi Menjaga Kondisi Kebersihan Sampah Di Tempat Berusaha}

Partisipasi menjaga kondisi kebersihan sampah di tempat berusaha artinya apakah pedagang menjaga kondisi kebersihan sampah di tempat berusahanya sendiri. Dalam hal ini memperhatikan sampah dapat dilihat pada Tabel 11.

Tabel 11. Partisipasi Menjaga Kondisi Kebersihan Sampah di Tempat Berusaha

\begin{tabular}{lccccc}
\hline No & $\begin{array}{c}\text { Tingkat } \\
\text { Partisipasi }\end{array}$ & $\begin{array}{c}\text { Alternatife } \\
\text { Skor }\end{array}$ & $\begin{array}{c}\text { Jumlah } \\
\text { Responden }\end{array}$ & $\begin{array}{c}\text { Persentase } \\
(\%)\end{array}$ & $\begin{array}{c}\text { Total } \\
\text { Skor }\end{array}$ \\
\hline 1 & Selalu & 3 & 90 & 97,82 & 270 \\
2 & Kadang- & 2 & 1 & 1,08 & 2 \\
& kadang & & 1 & 1,08 & 1 \\
3 & Tidak & 1 & 92 & 100,00 & 273 \\
\hline \multicolumn{7}{r}{ Sumber: Data Primer (2017) } & &
\end{tabular}

Hasil penelitian ini menunjukan bahwa, 90 responden $(97,82 \%)$ memilih selalu menjaga kondisi kebersihan sampah di tempat berusaha untuk kenyamanan pembeli dan pedagang tersebut, 1 responden $(1,08 \%)$ memilih kadangkadang karena kesibukan berjual, dan 1 responden $(1,08 \%)$ memilih tidak sama sekali karena kelelahan dan merasa kurangnya memproduksi sampah di tempat berusaha. 


\section{Partisipasi Menyediakan Tempat Sampah Sementara Sendiri}

Partisipasi menyediakan tempat sampah sementara sendiri artinya apakah pedagang menyediakan tempat sampah sementara sendiri di tempat penjualan pedagang tersebut, sebelum dibawah di TPS dapat dlihat pada Tabel 12.

Tabel 12. Partisipasi Menyediakan Tempat Sampah Sementara Sendiri

\begin{tabular}{cccccc}
\hline No & $\begin{array}{c}\text { Tingkat } \\
\text { Partisipasi }\end{array}$ & $\begin{array}{c}\text { Alternatife } \\
\text { Skor }\end{array}$ & $\begin{array}{c}\text { Jumlah } \\
\text { Responden }\end{array}$ & $\begin{array}{c}\text { Persentase } \\
(\%)\end{array}$ & $\begin{array}{c}\text { Total } \\
\text { Skor }\end{array}$ \\
\hline 1 & Selalu & 3 & 89 & 96,73 & 267 \\
2 & $\begin{array}{c}\text { Kadang- } \\
\text { kadang } \\
3\end{array}$ & 2 & 2 & 2,17 & 4 \\
Tidak & 1 & 1 & 1,08 & 1 \\
\hline & Jumlah & & 92 & 100,00 & 272
\end{tabular}

Sumber: Data Primer (2017)

Hasil penelitian ini menunjukan bahwa 89 responden (96,73\%) memilih selalu menyediakan tempat sampah sementara sendiri karena untuk mengumpulkan sampah sementara di tempat berusaha agar sampah tidak berkeliaran, 2 responden $(2,17 \%)$ memilih kadang-kadang karena sampah yang di produksi hanya sedikit, dan 1 responden $(1,08 \%)$ memilih tidak sama sekali karena tidak peduli terhadap kebersihan tempat berusaha.

\section{Partisipasi Kerjasama Antar Pedagang Dalam Menjaga Kebersihan}

Partisipasi kerjasama antar pedagang dalam menjaga kebersihan artinya apakah pedagang melakukan kerjasama/kebersamaan mengumpulkan sampah antar pedagang di sekitar lokasi penjualan dalam menjaga kebersihan dapat dilihat pada Tabel 13.

Tabel 13. Partisipasi Kerjasama Antar Pedagang Dalam Menjaga Kebersihan

\begin{tabular}{cccccc}
\hline No & $\begin{array}{c}\text { Tingkat } \\
\text { Partisipasi }\end{array}$ & $\begin{array}{c}\text { Alternatife } \\
\text { Skor }\end{array}$ & $\begin{array}{c}\text { Jumlah } \\
\text { Responden }\end{array}$ & $(\%)$ & $\begin{array}{c}\text { Total } \\
\text { Skor }\end{array}$ \\
\hline 1 & Selalu & 3 & 3 & 3,26 & 9 \\
2 & $\begin{array}{c}\text { Kadang- } \\
\text { kadang } \\
\text { Tidak }\end{array}$ & 2 & 1 & 1,08 & 2 \\
3 & 1 & 88 & 95,65 & 88 \\
\hline \multicolumn{7}{r}{ Sumber: Data Primer (2017) } & 92 & 100,00 & 99 \\
\hline
\end{tabular}

Hasil penelitian ini menunjukan bahwa, 3 responden $(3,26 \%)$ memilih selalu kerjasama antar pedagang dalam menjaga kebersihan karena adanya niat dari beberapa pedagang akan kepedulian terhadap kebersihan lingkungan tempat berusaha, 1 responden $(1,08 \%)$ memilih kadang-kadang karena hanya waktuwaktu tertentu saja mereka melakukan kerjasama antar pedagang, dan 88 responden $(95,65 \%)$ memilih tidak sama sekali karena tidak ada kekompakan antar pedagang untuk menjaga kebersihan di lingkungan tempat berusaha.

\section{Partisipasi Melakukan Evaluasi Bersama Terhadap Kebersihan Di Lingkungan Sekitar Pasar.}

Partisipasi melakukan evaluasi bersama terhadap kebersihan di lingkungan sekitar pasar artinya apakah pedagang melakukan evaluasi bersama seperti kerjabakti untuk kepentingan bersama terhadap kebersihan di lingkungan sekitar pasar dapat dilihat pada Tabel 14.

\begin{tabular}{|c|c|c|c|c|c|}
\hline \multicolumn{2}{|c|}{$\begin{array}{rr}\text { Tabel } 14 . & \mathbf{F} \\
& \text { T }\end{array}$} & $\begin{array}{ll}\text { Partisipasi } & \\
\text { Terhadap } & \mathbf{5} \\
\text { Sekitar Pasar }\end{array}$ & $\begin{array}{l}\text { Melakukan } \\
\text { Kebersihan }\end{array}$ & \multicolumn{2}{|c|}{$\begin{array}{c}\text { Evaluasi Bersama } \\
\text { Di Lingkungan }\end{array}$} \\
\hline$\overline{\mathrm{No}}$ & $\begin{array}{c}\text { Tingkat } \\
\text { Partisipasi }\end{array}$ & $\begin{array}{l}\text { Alternatife } \\
\text { Skor }\end{array}$ & $\begin{array}{c}\text { Jumlah } \\
\text { Responden }\end{array}$ & $\begin{array}{c}\text { Presentase } \\
(\%)\end{array}$ & $\begin{array}{l}\text { Total } \\
\text { Skor }\end{array}$ \\
\hline 1 & Selalu & 3 & 1 & 1,08 & 3 \\
\hline 2 & $\begin{array}{c}\text { Kadang- } \\
\text { kadang }\end{array}$ & 2 & 1 & 1,08 & 2 \\
\hline 3 & Tidak & 1 & 90 & 97,82 & 90 \\
\hline & Jumlah & & 92 & 100,00 & 95 \\
\hline
\end{tabular}

Hasil penelitian ini menunjukan bahwa, 1 responden $(1,08 \%)$ memilih selalu melakukan evaluasi bersama terhadap kebersihan di lingkungan sekitar pasar karena keinginan ikut serta dalam melakukan evaluasi, 1 responden (1,08\%) memilih kadang-kadang karena sangat jarang melakukan evaluasi tersebut, dan 90 responden $(97,82 \%)$ memilih tidak sama sekali karena tidak ada perintah dari atasan untuk melakukan evalusai tersebut, hanya di serahkan pada Tentara yang di tugaskan untuk melakukan evaluasi tersebut.

\section{Rekapitulasi Data}

Berdasarkan Data yang di peroleh pada tiap-tiap tabel kategori variabel di atas, kita dapat melhat rekapitulasi data keseluruhan pada Tabel 15. 
Tabel 15. Rekapitulasi Data

\begin{tabular}{|c|c|c|c|}
\hline No & Variabel & Skor & $\begin{array}{c}\text { Persentase } \\
\%\end{array}$ \\
\hline 1 & $\begin{array}{l}\text { Partisipasi Membuang Sampah } \\
\text { Pada Tempatnya }\end{array}$ & 247 & 14,99 \\
\hline 2 & $\begin{array}{l}\text { Partisipasi Menjaga Kondisi } \\
\text { Kebersihan Sampah Di Tempat } \\
\text { Berusaha }\end{array}$ & 273 & 14,94 \\
\hline 3 & $\begin{array}{l}\text { Partisipasi Membayar Retribusi } \\
\text { Sampah dan } \\
\text { Partisipasi Menyediakan Tempat } \\
\text { Sampah Sementara Sendiri }\end{array}$ & 272 & 14,88 \\
\hline 4 & $\begin{array}{l}\text { Partisipasi Menegur Orang Yang } \\
\text { Membuang Sampah Sembarangan }\end{array}$ & 184 & 10,07 \\
\hline 5 & $\begin{array}{l}\text { Partisipasi Mengumpulkan Sampah } \\
\text { Dagangan Ke TPS }\end{array}$ & 140 & 7,66 \\
\hline 6 & $\begin{array}{l}\text { Partisipasi Memberikan Gagasan } \\
\text { Untuk Kebersihan }\end{array}$ & 121 & 6,62 \\
\hline 7 & $\begin{array}{l}\text { Partisipasi Kerjasama Antar } \\
\text { Pedagang Dalam Menjaga } \\
\text { Kebersihan }\end{array}$ & 99 & 5,41 \\
\hline 8 & $\begin{array}{l}\text { Partisipasi Menghadiri } \\
\text { Rapat/Pertemuan Untuk } \\
\text { Membicarakan Masalah Kebersihan }\end{array}$ & 97 & 5,30 \\
\hline 9 & $\begin{array}{l}\text { Partisipasi Melakukan Evaluasi } \\
\text { Bersama Terhadap Kebersihan Di } \\
\text { Lingkungan Sekitar Pasar }\end{array}$ & 95 & 5,19 \\
\hline & Jumlah & 1.827 & 100,00 \\
\hline
\end{tabular}

Tabel 15 menunjukkan bahwa pada indikator pertama yaitu Partisipasi Membuang Sampah Pada Tempatnya mendapatkan skor 274 $(14,99 \%)$, kedua Partisipasi Menjaga Kondisi Kebersihan Sampah Di Tempat Berusaha mendapatkan skor 273 (14,99\%), ketiga Partisipasi Membayar Retribusi Sampah dan Partisipasi Menyediakan Tempat Sampah Sementara Sendiri skor mendapatkan skor 272 (14,88\%), keempat Partisipasi Menegur Orang Yang Membuang Sampah Sembarangan mendapat kan skor $184(10,07 \%)$, kelima Partisipasi Mengumpulkan Sampah Dagangan Ke TPS mendapatkan $140 \quad(7,66 \%)$, ketujuh Partisipasi Kerjasama Antar Pedagang Dalam Menjaga Kebersihan mendapatkan skor 99 (5,41\%), kedelapan Partisipasi Menghadiri Rapat/Pertemuan Untuk Membicarakan Masalah Kebersihan mendapatkan skor $97(5,30 \%)$, dan terakhir Partisipasi Melakukan Evaluasi Bersama Terhadap Kebersihan Di Lingkungan Sekitar Pasar 95 (5,19\%).

\section{KESIMPULAN DAN SARAN}

Kesimpulan

Partisipasi Pedagang dalam Pengelolaan Sampah di Pasar Pinasungkulan Kota Manado dalam kategori tertinggi yaitu partisipasi membuang sampah pada tempatnya, karena setiap pedagang menyediakan Tempat Sampah dimasing-masing tempat usaha, dan kategori terendah yaitu partisipasi dalam melakukan evaluasi bersama terhadap kebersihan lingkungan di sekitar pasar, karena tidak ada panggilan dari atasan. Berdasarkan hasil analisis deskriptif maka dapat diketahui bahwa angka indeks partisipasi pedagang pasar tergolong Tinggi.

\section{Saran}

Lebih ditingkatkan lagi partisipasi pedagang dalam pengelolaan sampah, dan diharapkan adanya kebijakan dan ketegasan dari Pemerintah kepada petugas serta pedagang untuk melaksanakan kerjasama.

\section{DAFTAR PUSTAKA}

Damsar, 1997. Kajian Lokasi Pedagang Kaki Lima Berdasarkan Preferensi PKL Serta Presepsi Masyarakat Sekitar Di Kota Pemalang.

Hadi, 2006. Analisis Faktor-Faktor Yang Mempengaruhi Pedagang dalam Pengelolaan Sampah Pasar.

Iren, 2011. Partisipasi Pedagang Dalam Menanggulangi Kebersihan Objek Wisata Di Kebun Raya Universitas Mulawarman Samarinda.

Kuncahyawati, 2014. Peranan Profitablitas Suku Bunga dan Nilai Tukar Dalam Mempengaruhi Pasar Modal Indonesia Selama Krisis Ekonomi.

Kuncoro, 2009. Faktor-faktor Penentu Tingkat Partisipasi Pedagang Dalam Pengelolaan Sampah Di Pasar Pagiarerngka Kota Pekan Baru.

Kurnawan, 2010. Partisipasi Pedagang Dalam Pengelolaan Kebersihan Objek Wisata.(studi deskriptif kualitatif tentang partisipasi pedagang dalam pengelolaan kebersihan objek wisata Taman Satwa Taru Jurug Surakarta).

Newstrom, 2004. Syafari, 2010. Partisipasi Pedagang Terhadap Pengembangan Pasar Night Market Di Surakarta. Diss. UNS. 